\title{
INFLUENCE OF DIPHENYLOXIDE DISULFONATE SURFACTANTS ON BIODEGRADATION OF HYDROCARBONS
}

\section{J.D. ROUSE* \\ OS. HIRATA \\ K. FURUKAWA}

Received: $18 / 09 / 00$

Accepted: 26/06/01
Department of Civil and Environmental Engineering

Kumamoto University, Kurokami 2-39-1

Kumamoto 860-8555, Japan

* to whom all correspondence should be addressed e-mail: jdrouse@yahoo.com fax: +81-96-342-3507

\begin{abstract}
Testing was conducted with anionic diphenyloxide disulfonate (DPDS) surfactants (C12 and C16 alkyl moieties) with naphthalene in aqueous systems and phenanthrene in soil systems to investigate the influence of these surfactants on biodegradation of hydrocarbons. A potential for enhancement in the degradation of naphthalene was seen in C12-DPDS amended assays at low surfactant concentrations, predominately below the critical micelle concentration (CMC). The overall trend for both $\mathrm{C} 12-$ and C16-DPDS assays indicated decreasing efficiency in degradation of naphthalene with increasing surfactant concentration, with no correlation to the CMCs. In the soil-slurry assays, surfactant-free controls and assays with the lowest (sub-CMC) surfactant additions demonstrated the first phenanthrene mineralization responses followed by the mid-level (sub-CMC) surfactant-amended assays. Approximately 3 months later, a supra-CMC C12-DPDS sample had a strong response. In saturated soil (mud) systems, mineralization only occurred in the surfactant-free controls and in assays with the lowest (sub-CMC) additions during 5 months of testing. The lowest surfactant additions, however, were effective in enhancing mineralization of phenanthrene, with the first-order constant for the C12-DPDS amended assays being increased by a factor of 5 over that of the surfactant-free controls.
\end{abstract}

KEY WORDS: anionic surfactant, solubilization, naphthalene, phenanthrene, soil, sorption.

\section{INTRODUCTION}

Subsurface contamination by petroleum-based products has been an issue of concern in recent years. The potential for surfactants to enhance the extraction of petroleum hydrocarbons (HCs) in non-biological remedial schemes has been a subject of considerable interest. Vis-a-vis, the potential for surfactants to increase the apparent aqueous solubility of hydrophobic compounds has led to their being considered as a means of improving contaminant accessibility for microorganisms. The influence of surfactants on biodegradation of HCs has continued to be a stimulating topic of research and discussion (Rouse et al., 1994; Köhler et al., 1994; Churchill et al., 1995; Liu et al., 1995; Volkering et al., 1995; Deschenes et al., 1995; Jahan et al., 1997; Tiehm et al., 1997; Boonchan et al., 1998).

Surfactants, or surface-active agents, are amphipathic molecules consisting of a hydrophilic polar 
Table 1. Characteristics of surfactants used in this research.

\begin{tabular}{|c|c|c|c|c|}
\hline Surfactant & $\begin{array}{l}\text { Average MW } \\
\quad\left(\mathrm{g} \mathrm{mol}^{-1}\right)\end{array}$ & $\mathrm{CMC}^{\mathrm{b}}(\mathrm{mM})$ & $\begin{array}{c}\text { Micellar } \\
\text { surface tension }^{\mathrm{b}} \\
\left(\mathrm{mN} \mathrm{m}^{-1}\right) \\
\end{array}$ & $\begin{array}{l}\text { design molecular } \\
\text { formula }\end{array}$ \\
\hline C12-DPDS & 542 & 2.5 & 45 & $\mathrm{C}_{12} \mathrm{H}_{25} \mathrm{C}_{12} \mathrm{H}_{7} \mathrm{O}\left(\mathrm{SO}_{3} \mathrm{Na}\right)_{2}$ \\
\hline C16-DPDS & $642^{\mathrm{a}}$ & 1.5 & 46 & $\mathrm{C}_{16} \mathrm{H}_{33} \mathrm{C}_{12} \mathrm{H}_{7} \mathrm{O}\left(\mathrm{SO}_{3} \mathrm{Na}\right)_{2}$ \\
\hline
\end{tabular}

a Average MW of the C16-DPDS is of the DOWFAX product which includes some variation from the design molecular formula (see text).

${ }^{\mathrm{b}} \mathrm{CMC}$ and micellar solution surface tension determined by capillary rise method in nutrient solution.

"head" and a hydrophobic nonpolar "tail". Surfactants can be categorized by the ionic charge of their polar moiety: nonionic, anionic, cationic, and zwitterionic (containing both anionic and cationic charges). Surfactants tend to migrate to surfaces and alter free energy states or interfacial tensions (free energy per unit area), which can result in the formation of emulsions, greatly increasing the interfacial area between immiscible liquids (e.g., oil and water). Both reduction of free energy and increase in surface area can contribute to an enhanced rate of desorption or dissolution. Another characteristic of surfactants is their tendency to form aggregates, or micelles, when the critical micelle concentration (CMC) is surpassed (Rosen, 1989). Partitioning of HCs into the micellar core, or solubilization, greatly increases the concentrations of poorly soluble compounds in solution. Solubilization potential can be characterized by the micelle-water partition coefficient, $\mathrm{K}_{\mathrm{m}}$, and the molar solubilization ratio, MSR (Edwards et al., 1991).

With addition of surfactants to microbial systems, both enhancements and inhibitions of biodegradation of organic compounds have been observed. Most research has focused on nonionic surfactants. Ionic surfactants have been noted for their damaging effects on cell membranes (Lupton and Marshall, 1979; Shabtai and Gutnick, 1985; Swisher, 1987) and may thus be considered unsuitable for use in biological systems. However, enhancements in oxygen uptake rates with a HC substrate using anionic diphenyloxide disulfonate (DPDS) surfactants with mid range alkyl lengths (10 to 16 carbon units) have been noted (Rouse et al., 1995b; Smith, 1995).
The objective of this research was to further assess the influence of DPDS surfactants on the biodegradation of HCs. The first phase of this study involved the biodegradation of a moderately hydrophobic, relatively soluble HC (naphthalene) in aqueous systems. This allowed for an assessment of the influence of these surfactants on microbial utilization of a compound in solution, apart from sorption interactions. The second phase involved mineralization studies with a hydrophobic, poorly soluble HC (phenanthrene) in soil-slurry and soil-mud systems to evaluate the influence of these surfactants on the bioavailability of a predominately sorbed compound. The surfactants selected for this research have been well characterized with respect to CMC formation (Dimonie et al., 1990) and their potentials for low precipitation and sorption losses in soil environments (Rouse et al., 1993; Shiau et al., 1995; Deshpande et al., 2000). Furthermore, they have demonstrated success in the abiotic aspects of subsurface remediation (Knox et al., 1997; Sabatini et al., 1997; Knox et al., 1999). A point of consideration in this study is the potential for in situ surfactant-enhanced bioremediation in a polishing phase following a surfactant-aided pumpand-treat operation. Under such conditions, remnant contaminant and applied surfactant would both be present.

\section{MATERIALS AND METHODS Surfactants}

The alkyl DPDS surfactants used in this research were from the DOWFAX series as supplied by Dow Chemical Co. (Midland, MI, USA). They consisted of C12-DPDS and C16-DPDS, where the 
Table 2. Surfactant solubilization properties for naphthalene and phenanthrene.

\begin{tabular}{|l|c|c|c|c|}
\hline \multirow{2}{*}{ Surfactant } & \multicolumn{2}{|c|}{ Naphthalene $^{\text {a }}$} & \multicolumn{2}{c|}{ Phenanthrene $^{\text {b }}$} \\
\hline & MSR & $\log \mathrm{K}_{\mathrm{m}}$ & MSR & $\log \mathrm{K}_{\mathrm{m}}$ \\
\hline C12-DPDS & 0.1045 & 4.32 & $0.0406^{\mathrm{c}}$ & 5.58 \\
\hline C16-DPDS & 0.1320 & 4.41 & $0.0592^{\mathrm{c}}$ & 5.74 \\
\hline
\end{tabular}

a Solubilization of naphthalene as per Rouse et al., 1993.

b Solubilization of phenanthrene as per Hasegawa et al., 1997.

${ }^{\mathrm{c}}$ MSR for phenanthrene determined by calculation, given $\mathrm{K}_{\mathrm{m}}$.

C\# designates the number of carbons in the alkyl moiety. Characteristics of these surfactants are shown in Table 1. The C12-DPDS (an experimental, unregulated surfactant) was purely monoalkylated and disulfonated (MADS). The C16-DPDS (commercial product termed "DOWFAX 8390") was approximately $20 \%$ by weight dialkylated and $10 \%$ monosulfonated with the remainder being MADS. The surfactants were received in liquid form (C12-DPDS, 9.4\% actives; C16-DPDS, 36\% actives) with less than $0.5 \% \mathrm{NaCl}$. The C16-DPDS has been shown to be biodegradable in activated sludge and soil systems (Dow Chem., 1997). The C12-DPDS, though of the same basic structure as the C16-DPDS, is not yet classified. Solubilization data from the literature for these surfactants are summarized in Table 2.

\section{Hydrocarbons}

Naphthalene and phenanthrene were guaranteed reagent grade products purchased from Nacalai Tesque, Inc., Japan. Naphthalene $\left(\mathrm{C}_{10} \mathrm{H}_{8}\right)$ has a water solubility of $30 \mathrm{mg} \mathrm{l}^{-1}$ and $\log \mathrm{K}_{\mathrm{ow}}$ of 3.36 and phenanthrene $\left(\mathrm{C}_{14} \mathrm{H}_{10}\right)$ has a solubility of $1 \mathrm{mg} \mathrm{l}^{-1}$ and $\log \mathrm{K}_{\mathrm{ow}}$ of 4.52 (Knox et al., 1993). Labeled phenanthrene $\left[9-{ }^{14} \mathrm{C}\right.$ ], consisting of $250 \mu \mathrm{Ci}$ (specific activity, $55 \mathrm{Ci} \mathrm{mol}^{-1}$ ) was obtained from Moravek Biochemicals, Inc. (Brea, Calif.). Phenanthrene spiking solutions for mineralization assays were mixed in methanol at predetermined ratios of labeled and unlabeled product. Behavior of the labeled compound was assumed to be representative of the whole mixture.

\section{Soil}

For the soil-amended experiments, an unwelded tuff of pumice flow, typical to the central and southern parts of Kyushu Island, Japan, was used. The soil is locally known as "Shirasu" (meaning white sand) and was composed of $1.9 \%$ gravel, $61.8 \%$ sand, $25.3 \%$ silt and $11.0 \%$ clay (Kitamura and Takada, 1998). The soil is light brown in color and was determined to have a fraction of organic matter of $0.034(3.4 \%)$ by incineration at $550{ }^{\circ} \mathrm{C}$. It was stored in plastic bags under dark conditions with moisture content of about $12 \%$ (determined by drying at $105^{\circ} \mathrm{C}$ ).

\section{Microbial enrichments}

Mixed microbial cultures were enriched using the respective $\mathrm{HC}$ substrates as the sole organic carbon source. For both the naphthalene and phenanthrene enrichments, the initial seed was an activated sludge maintained in synthetic medium. HC was supplemented to maintain visible excess. Supplemental nutrients consisted of (per liter) $100 \mathrm{mg} \mathrm{KH} \mathrm{PO}_{4}, 24 \mathrm{mg} \mathrm{CaCl}\left(\mathrm{H}_{2} \mathrm{O}\right)_{2}, 40 \mathrm{mg}$ $\mathrm{MgSO}_{4}\left(\mathrm{H}_{2} \mathrm{O}\right)_{7}, 84 \mathrm{mg} \mathrm{NaNO}, 270 \mathrm{mg} \mathrm{NH} 4 \mathrm{Cl}$, $350 \mathrm{mg} \mathrm{K}_{2} \mathrm{HPO}_{4}$ and $9 \mathrm{mg} \mathrm{FeSO}{ }_{4}\left(\mathrm{H}_{2} \mathrm{O}\right)_{7}$ (including $5 \mathrm{mg}$ EDTA $\cdot 2 \mathrm{Na}$ as a chelating agent for $\mathrm{Fe}$ ). Micro-nutrients consisted of (per liter) $0.25 \mathrm{mg}$ $\mathrm{CuSO}_{4}\left(\mathrm{H}_{2} 0\right)_{5}, 0.43 \mathrm{mg} \mathrm{ZnSO}_{4}\left(\mathrm{H}_{2} \mathrm{O}\right)_{7}, 0.24 \mathrm{mg}$ $\mathrm{CoCl}_{2}\left(\mathrm{H}_{2} \mathrm{O}\right)_{6}, 0.99 \mathrm{mg} \mathrm{MnCl}_{2}\left(\mathrm{H}_{2} \mathrm{O}\right)_{4}, 0.22 \mathrm{mg}$ $\mathrm{Na}_{2} \mathrm{MoO}_{4}\left(\mathrm{H}_{2} \mathrm{O}\right)_{2}, 0.19 \mathrm{mg} \mathrm{NiCl}{ }_{2}\left(\mathrm{H}_{2} \mathrm{O}\right)_{6}, 0.11 \mathrm{mg}$ $\mathrm{Na}_{2} \mathrm{SeO}_{4}$ and $0.014 \mathrm{mg} \mathrm{H}_{3} \mathrm{BO}_{3}$. The naphthalene degrading enrichment was transferred weekly and had been maintained for 10 months prior use. Levels of naphthalene degrading organisms (as biomass) were estimated by suspended solids (SS) (APHA, 1995). The phenanthrene degrading enrichment was transferred every 3 to 4 weeks and had been maintained for one year prior to 
use. Phenanthrene degrading organisms were enumerated by the phenanthrene-spread plate method (Laha and Luthy, 1991).

\section{Naphthalene biodegradation assays}

Glass jars (68-ml capacity) with tightly fitting plastic screw caps were used for the naphthalene biodegradation assays involving aqueous solutions. A stock naphthalene solution was maintained at saturation with excess product. The stock solution was passed through 5B quantitative ashless filter paper immediately prior to use with some being discarded to satisfy sorption losses. This stock was diluted with other component solutions for a resulting naphthalene concentration of $6 \mathrm{mg} \mathrm{l}^{-1}$ in assays. The microbial seed was prepared from the enrichment culture by washing twice in $0.10 \mathrm{M}$ phosphate buffer (centrifuging at $3,000 \times \mathrm{g}$ for $10 \mathrm{~min}$ ). After washing, the seed was messed-up with buffer to a SS of $500 \mathrm{mg} \mathrm{l}^{-1}$. This suspension was diluted to a biomass concentration of $20 \mathrm{mg} \mathrm{l}^{-1}$ in assays. Preparation of assays consisted of (in order of addition) aerated deionized water (to achieve a final volume of $50 \mathrm{ml}$ ), supplemental nutrient solutions (see Microbial enrichments), surfactant stock solution (volume depending on the experimental design), $10 \mathrm{ml}$ naphthalene stock solution and $2 \mathrm{ml}$ microbial seed. Assay vessels were incubated in a thermostatically controlled ML-10F Cool Bath Shaker (TAITEC, Hoshiya, Japan) at $25{ }^{\circ} \mathrm{C}$ with mixing at $90 \mathrm{rpm}$.

\section{Phenanthrene mineralization in soil-slurries}

Mineralization assays for soil-slurry systems were conducted in $250-\mathrm{ml}$ bioflasks constructed to order by Iwaki Glass Co. (Kyoto, Japan). A 12-ml vial was fixed to the side arm, which was sloped down 15 degrees from horizontal. The bioflask mouth and vial were sealed with butyl rubber stoppers. A $2 \mathrm{~N} \mathrm{NaOH}$ solution was placed in the side-arm vial to trap evolved $\mathrm{CO}_{2}$ and vials were opened at prescribed times to draw $\mathrm{NaOH}$ samples by plastic syringe for counting of ${ }^{14} \mathrm{C}$ label. Sampling was done by first discarding $0.5 \mathrm{ml}$ of $\mathrm{NaOH}$ solution and then separately drawing two 0.5-ml samples for duplicate counts. Sampling was done on a weekly basis, during which time exposure to oxygen occurred. The fourth sampling event from an original $7.0 \mathrm{ml}$ left a remainder of $1.0 \mathrm{ml}$, which was discarded. The side arm was then rinsed and refilled. Periodic checks of late term hydroxide solutions indicated $\mathrm{pH}$ values greater than 10 .

Surfactant amended soil-slurry assays were setup in duplicate and surfactant-free controls in triplicate and a singular $\mathrm{HgCl}_{2}\left(250 \mathrm{mg} \mathrm{l}^{-1}\right)$ sterile control was included. Soil-slurries were made at a 1:10 ratio (soil:water weight basis) with an $80 \mathrm{ml}$ solution accounting for soil moisture (i.e., $9 \mathrm{~g}$ soil including $12 \%$ moisture, or $1 \mathrm{ml}$ moisture, plus 79 $\mathrm{ml}$ solution). Preparations consisted of (in order of addition) $4.5 \mathrm{~g}$ soil (half the design total), aerated deionized water, supplemental nutrients (see Microbial enrichments) and $0.2 \mathrm{ml}$ of phenanthrene stock (combined labeled and ordinary product in methanol). Slurries were then stirred for $2 \mathrm{hr}$ to allow for evaporation of methanol and stored overnight. Next, surfactant stock (depending on experimental design) or $\mathrm{HgCl}_{2}$ solution (1.6 ml of $12.5 \mathrm{~g} \mathrm{l}^{-1}$ stock) were mixed into the respective slurries. Finally, the remaining $4.5 \mathrm{~g}$ of soil was added and mixed. The $\mathrm{NaOH}$ solution was then placed into the side-arm vial and flasks were stoppered. The bioflasks were stored in the dark at $25^{\circ} \mathrm{C}$ and mixed by magnetic stirrer for 5 min daily. Soil was added in two parts-before and after addition of the methanol solution - to allow for inclusion of indigenous soil microbiota that had not been exposed to methanol. The phenanthrene spiking solution contained 355,000 dpm of ${ }^{14} \mathrm{C}$ and $1.2 \mathrm{mg}$ of phenanthrene per $0.2-\mathrm{ml}$ addition. Each assay thus had a phenanthrene concentration of $15 \mathrm{mg} \mathrm{l}^{-1}$ solution or $0.15 \mathrm{mg} \mathrm{g}^{-1}$ dry soil (not accounting for soil-water distribution). For some late term samples, 1:10 dilutions were made (as noted in Results). A supplemental addition of phenanthrene $(0.1 \mathrm{mg}$ with $440,000 \mathrm{dpm}$ label) was added via $0.2 \mathrm{ml}$ of methanol solution to $135 \mathrm{ml}$ of nutrient solution in a bioflask. The methanol was allowed to evaporate for a few hours under stirring conditions and $15 \mathrm{ml}$ of wellmixed slurry from a selected sample was then introduced.

\section{Phenanthrene mineralization in saturated soil (mud)}

Mineralization assays for saturated soil (mud) systems were conducted in 225-ml glass jars with tightly fitting plastic screw caps with Teflon cushions. Glass test tubes (14-ml capacity) containing a $2 \mathrm{~N} \mathrm{NaOH}$ solution (10 ml maximum) were 
inserted into the soil to trap evolved $\mathrm{CO}_{2}$. Amended solutions were added to soil to achieve moisture saturated. Saturation was defined as having about $1 \mathrm{~mm}$ of standing water immediately after mixing. With the Shirasu soil, this condition was met by adding $20 \mathrm{ml}$ of solution to $45 \mathrm{~g}$ soil (soil including $12 \%$ moisture, thus $25 \mathrm{ml}$ liquid and $40 \mathrm{~g}$ dry soil). Surfactant-amended assays were setup in duplicate and surfactant-free controls in triplicate and a singular $\mathrm{HgCl}_{2}\left(250 \mathrm{mg} \mathrm{l}^{-1}\right)$ sterile control was included. Preparation of assays consisted of (in order of addition with thorough mixing) $9 \mathrm{~g}$ soil ( $1 / 5$ of total), $15 \mathrm{ml}$ aerated deionized water and $0.5 \mathrm{ml}$ of phenanthrene stock (labeled and ordinary product in methanol). Sample containers were left open and stirred intermittently for $6 \mathrm{hr}$ to allow for evaporation of methanol and distribution of phenanthrene. Test tubes containing $6.0 \mathrm{ml}$ of $\mathrm{NaOH}$ solution were then inserted and the jars were capped and stored at $5{ }^{\circ} \mathrm{C}$ in the dark for $28 \mathrm{~d}$ to allow for sorption maturation. Thereafter, the jars were opened and the $\mathrm{NaOH}$ solution was sampled (to check for activity during cold storage). The remaining components were then added, consisting of deionized water (including compensation for evaporative losses, determined by weight), supplemental nutrients (see Microbial enrichments), surfactant stock or $\mathrm{HgCl}_{2}$ solution, $18 \mathrm{~g}$ of soil and $1.0 \mathrm{ml}$ of phenanthrene degrading enrichment $\left(10^{5}\right.$ cells per $\mathrm{g}$ soil). The final $18 \mathrm{~g}$ of soil was then added (total $45 \mathrm{~g}$ ) and the contents were mixed with a steel spatula. The $\mathrm{NaOH}$ solution tubes were then replaced and the jars capped. The jars were stored at $25{ }^{\circ} \mathrm{C}$ in boxes that were tilted 20 degrees from horizontal with the direction of tilt being changed daily (to imitate a weak gradient). The phenanthrene spiking solution contained $888,000 \mathrm{dpm}$ of ${ }^{14} \mathrm{C}$ and $3.0 \mathrm{mg}$ of phenanthrene per $0.5-\mathrm{ml}$ addition. Each assay thus had a phenanthrene concentration of $120 \mathrm{mg} \mathrm{l}^{-1}$ solution or $0.075 \mathrm{mg} \mathrm{g}^{-1}$ dry soil (not accounting for soil-water distribution). Sampling of $\mathrm{NaOH}$ solutions was done in singular. Periodic checks of late term hydroxide solutions indicated $\mathrm{pH}$ values greater than 10.

\section{Analytical methods}

Naphthalene was quantified by high performance liquid chromatography with UV detection at 225 nm (Gilson Medical Electronics, Inc., Middleton,
WI). For chromatographic separation, Shodex Asahipak medium (C18 reverse phase, $5-\mu \mathrm{m}$ particle size) was used in a $25-\mathrm{cm}, 4.6-\mathrm{mm}$ diameter column (Shimadzu, Inc., Kyoto) with a 90\% methanol mobile phase. In phenanthrene mineralization assays, counting for ${ }^{14} \mathrm{C}$ as $\mathrm{dpm}$ was done with a 1500 Tri-Carb Liquid Scintillation Analyzer (Packard Inc., Tokyo) using a fiveminute count period. Sample volumes of $0.5 \mathrm{ml}$ were mixed with $5.0 \mathrm{ml}$ Hionic-Fluor LSC cocktail (Packard) for counting. Quantification of total accumulated ${ }^{14} \mathrm{C}$ as $\mathrm{dpm}$ was done by an ongoing mass balance accounting for changes in $\mathrm{NaOH}$ solution volume. Surfactant concentrations were estimated from surface tension data developed by the capillary rise method (Rouse et al., 1996). Surface tension was calculated from meniscus rise by an iterative method, as described by Adamson (1990). Duotest $\mathrm{pH}$ indicator paper (Macherey-Nagel GmbH \& Co., Duren, Germany) with a $0.3 \mathrm{pH}$ unit accuracy was used to measure $\mathrm{pH}$ in radio-isotope experiments.

\section{RESULTS AND DISCUSSION Biodegradation of naphthalene in aqueous systems}

The initial concentration for naphthalene in the biodegradation assays was set at $6 \mathrm{mg} \mathrm{l}^{-1}$. In preliminary tests (not shown), this concentration was shown to be sufficiently low to avoid toxicity effects while leaving adequate response time for evaluation of degradation rates. Characterization studies (not shown) demonstrated that $\mathrm{HgCl}_{2}$ was effective in stopping activity but $\mathrm{NaN}_{3}$ had no effect (both at $250 \mathrm{mg} \mathrm{l}^{-1}$ ). In tests without microbial seed, volatilization losses of naphthalene did not occur and the amount of seed was shown to proportionally influence degradation, thus supporting the supposition that the disappearance of naphthalene was biological in nature.

Results of naphthalene degradation assays fit well to a zero-order interpretation. Degradation rates of assays amended with C12- and C16-DPDS normalized to results of surfactant-free controls are shown in Figs. 1 and 2, respectively. Surfactantfree controls during the period of testing with C12-DPDS had an average degradation rate (with standard error) of $1.48 \pm 0.17 \mathrm{mg} \mathrm{l}^{-1} \mathrm{hr}^{-1}$ and controls run during the C16-DPDS assays, $2.00 \pm 0.25$ $\mathrm{mg} \mathrm{l}^{-1} \mathrm{hr}^{-1}$. These averaged values can be multiplied by the respective normalized rates (unitless) 


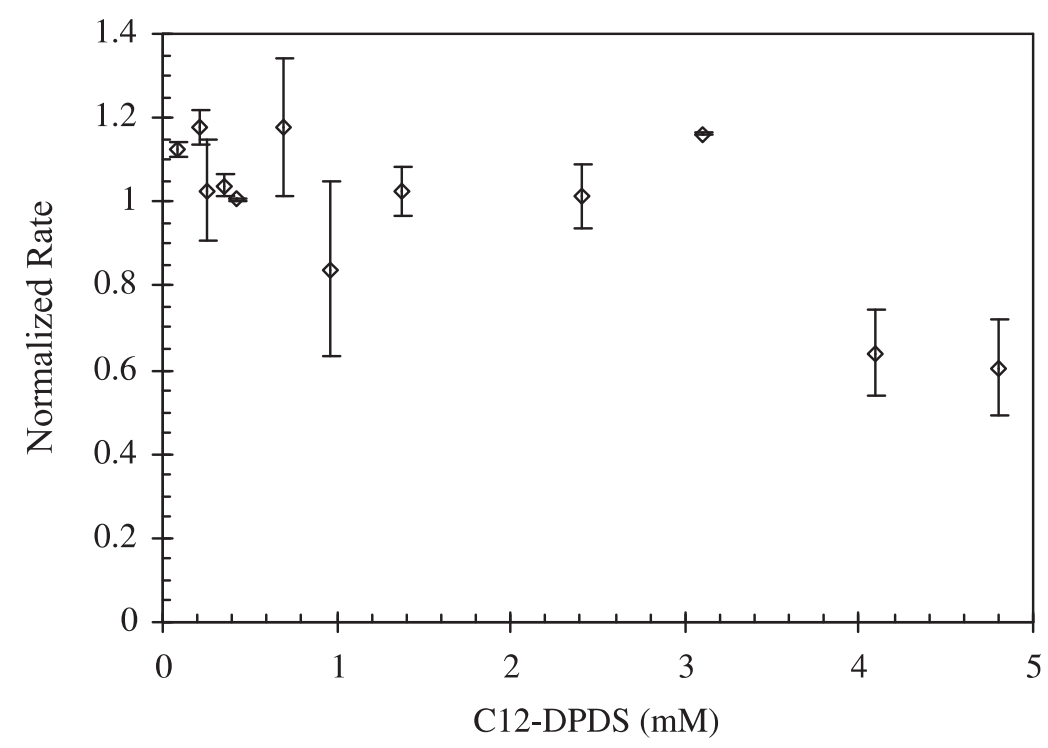

Figure 1. Normalized rates of naphthalene degradation in aqueous systems versus initial C12-DPDS concentration. Bars indicate the range of $95 \%$ confidence intervals. Rates greater than 1.0 indicate enhancement of biodegradation.

in Figs. 1 or 2 to obtain estimates of the actual rates $\left(\mathrm{mg} \mathrm{l}^{-1} \mathrm{hr}^{-1}\right)$. Naphthalene degradation rates in C12-DPDS amended assays with surfactant concentrations up to about $3 \mathrm{mM}$ showed a level trend above unity indicating some potential for enhancement. However, an overall interpretation of the results (to ca. $5 \mathrm{mM}$ ) would imply a decreasing trend in efficiency with increasing surfactant concentration. Furthermore, the CMC $(2.5 \mathrm{mM})$ does not appear to be a pivotal point. In this case, where the $\mathrm{HC}$ substrate is soluble, the influence of surfactants would be understood best in terms of direct interactions with microorganisms. This is further emphasized here where most of the potential for enhancement (or lack of inhibition) was well below the $\mathrm{CMC}$ in the absence of micelle formation. However, where inhibition was observed at supra-CMC levels, reduction of naphthalene concentrations in the strictly aqueous phase (due to partitioning into the micellar core) could be a factor. It can be estimated, though, that micellization at the relatively low supra-CMC levels used here would only result in a reduction of aqueous phase naphthalene to about one-third the applied concentration (Rouse et al., 1995a), which would not be significant. Furthermore, studies on partitioning of naphthalene from DPDS solutions have shown that partitioning of naphthalene from micelles is rapid compared to microbial utilization rates (Rouse et al., 1995b).
Therefore, the inhibitions observed at supraCMC levels could only be associated with interactions of the surfactant with the organisms and not the substrate. Results of C16-DPDS amended assays indicated no potential for enhancement in naphthalene utilization at surfactant concentrations throughout the range of testing. In addition, as with C12-DPDS, a decrease in the rate of naphthalene degradation (or increase in inhibition) with increasing surfactant concentration was evident (Fig. 2).

Surfactant (ad)sorption on soil increases with surfactant concentration in solution up to the CMC after which surface sorption sites are fully occupied. If this concept is applicable to surfactant interaction with microorganisms, inhibitory effects might be thought to reach a maximum at the CMC. Where this is not the case, perhaps interaction of surfactants with cell membranes does not behave in the same manner as surface sorption (i.e., not Langmurian in nature) but that extensive (ab)sorption or partitioning into the pool of like-structured biosurfactants in microbial membranes may be occurring. Previous work on sorption of DPDS into biomass demonstrated a non-maximized value of $0.04 \mathrm{~g} \mathrm{~g}^{-1}$ (Rouse et al., 1995b), which is 20 times higher than that which is expected for soil surface coverage (Rouse et al., 1993). Interactions between surfactants and cell envelopes could result in interference with mem- 


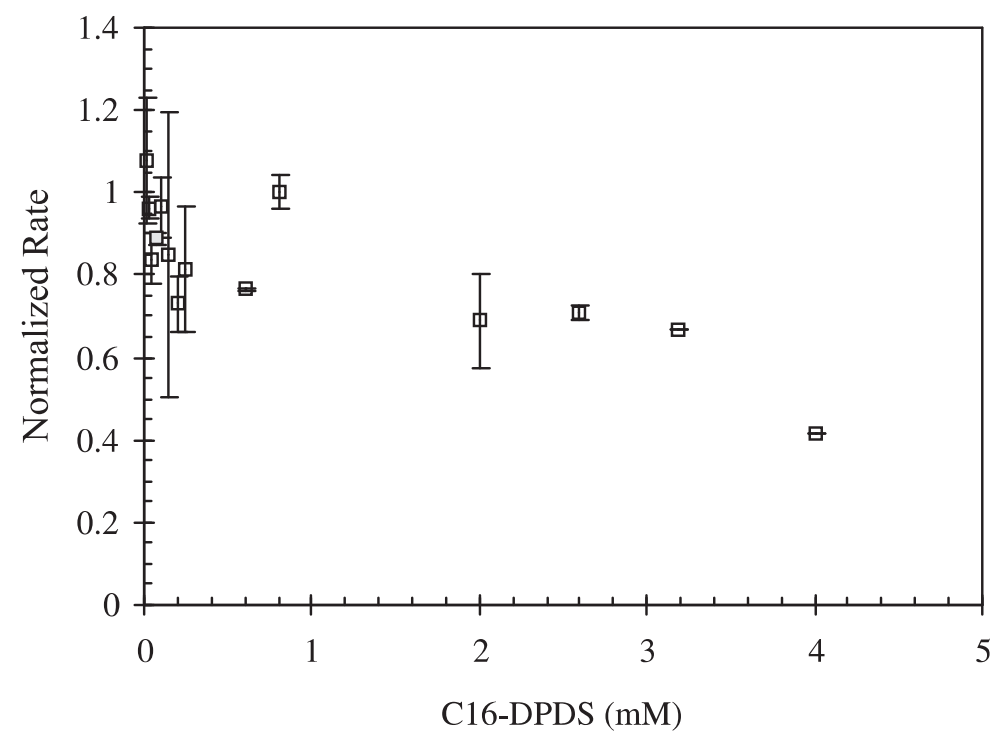

Figure 2. Normalized rates of naphthalene degradation in aqueous systems versus initial C16-DPDS concentration. Bars indicate the range of $95 \%$ confidence intervals. Rates less than 1.0 indicate inhibition of biodegradation.

brane functions or loss of integrity leading to inhibition. However, increased fluidity of membranes by low surfactant concentrations has been offered as a possible reason for enhancements in microbial activity by Van Hoof and Rogers (1992). Enhancements at low concentrations of C12-DPDS versus C16-DPDS may be an indication of greater steric compatibility; i.e., the C12DPDS may be a better match with membrane lipids.

\section{Mineralization of phenanthrene in soil-slurries}

In a soil system, the distribution of hydrophobic compounds between aqueous and solid phases normalized to the soil's organic carbon content can be expressed as

$$
\mathrm{K}_{\mathrm{Oc}}=\mathrm{K}_{\mathrm{d}} / \mathrm{f}_{\mathrm{Oc}}=\left[\mathrm{HC}_{\mathrm{S}}\right] /\left(\left[\mathrm{HC}_{\mathrm{W}}\right] * \mathrm{f}_{\mathrm{Oc}}\right)
$$

where $\left[\mathrm{HC}_{\mathrm{s}}\right]$ is the concentration of the $\mathrm{HC}$ contaminant in the solid phase $\left(\mathrm{mol} \mathrm{kg}^{-1}\right),\left[\mathrm{HC}_{\mathrm{w}}\right]$ is the concentration of the $\mathrm{HC}$ in the aqueous phase $(\mathrm{M}), \mathrm{K}_{\mathrm{d}}$ is the distribution coefficient, and $\mathrm{f}_{\mathrm{oc}}$ is the fraction of organic carbon in the solid (soil) phase. Considering the Shirasu soil used here with a fraction of organic matter $\left(\mathrm{f}_{\mathrm{om}}\right)$ of $0.034, \mathrm{f}_{\mathrm{oc}}$ can be assumed to be about 0.017 . This normalized distribution coefficient $\left(\mathrm{K}_{\mathrm{oc}}\right)$ has been shown by Karickhoff et al (1979) to correlate to a compound's octanol-water partition coefficient $\left(\mathrm{K}_{\mathrm{ow}}\right)$.
This correlation has been rendered in simplified form by Hassett et al (1980) as

$$
\mathrm{K}_{\mathrm{oc}}=0.48 \mathrm{~K}_{\mathrm{ow}}
$$

Considering the 1:10 soil-water ratio used here, using Eqs. 1 and 2 it can be shown that with the $1.2 \mathrm{mg}$ of phenanthrene added to a surfactantfree sample, the aqueous concentration at equilibrium would be about $5 \mu \mathrm{g} \mathrm{l}^{-1}$. If $\mathrm{f}_{\text {oc }}$ was half the assumed value above (i.e., $\mathrm{f}_{\mathrm{oc}}=0.008$ ), the equilibrium phenanthrene concentration would be 10 $\mu \mathrm{g} \mathrm{l}^{-1}$. With either assumption, it was considered sufficiently low (at least two orders of magnitude below the solubility limit) to probe for surfactant effects on the bioavailability of a sorbed HC.

Biodegradation studies involving $\mathrm{HC}$ in soil systems have been carried out with (Laha and Luthy, 1991; Tiehm et al., 1997) and without (Aronstein et al., 1991; Aronstein and Alexander, 1993) introduction of non-indigenous microbial seeds. In this study, it was decided to apply some degree of patience in allowing the natural soil microbiota to respond with the option of a later addition of seed. C12-DPDS (Fig. 3) and C16-DPDS (Fig. 4) were applied over two orders of magnitude inclusive of the CMCs. During the first 4 weeks, no significant mineralization responses occurred; thus on day $28,0.5 \mathrm{ml}$ of the phenanthrene degrading enrichment was added to each sample (ca. $10^{5}$ 


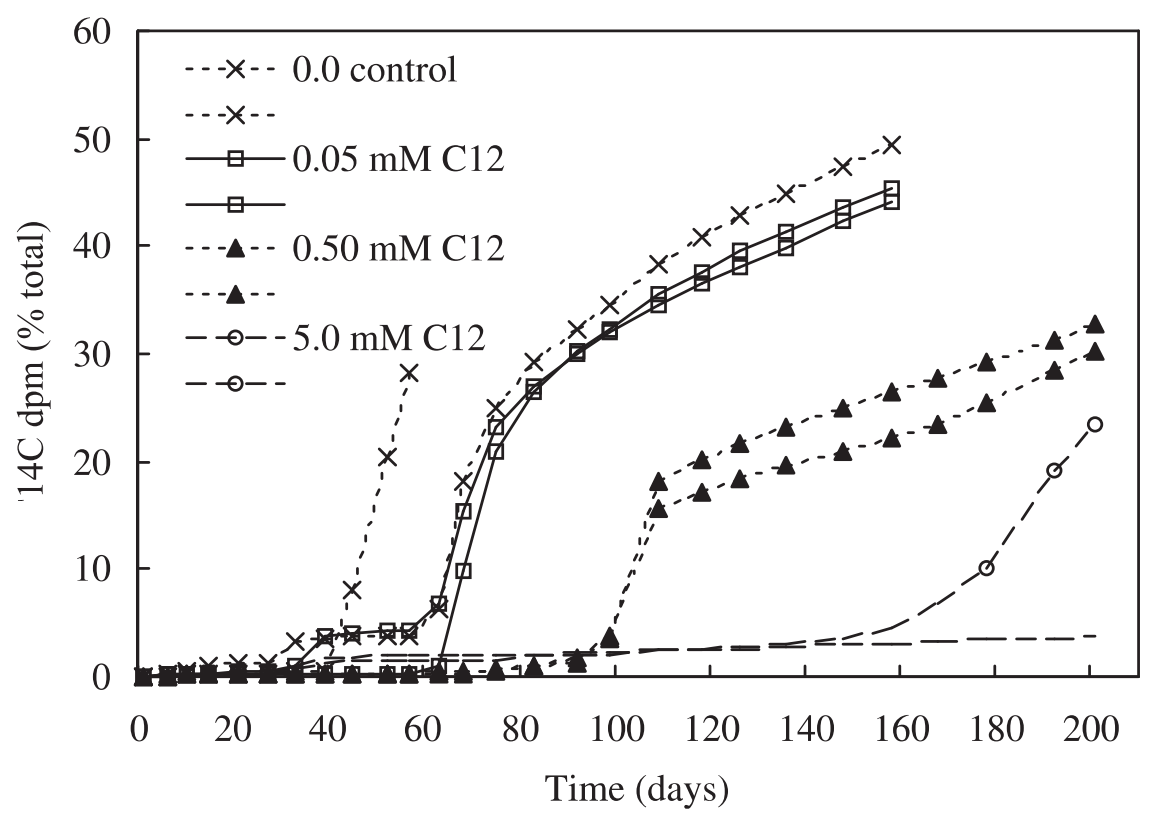

Figure 3. Accumulation of label from mineralized phenanthrene $\left({ }^{14} \mathrm{C} \mathrm{dpm}\right)$ versus time for soil-slurry systems with C12-DPDS (and controls). On day $28,0.5 \mathrm{ml}$ of phenanthrene- degrading culture was added to each sample. On day $60,2.0 \mathrm{ml}$ of control that had demonstrated early growth was distributed to each remaining sample.

cells per g soil). Short-lived responses (mineralization levels to about 3\%) were immediately evidenced in a few samples over the complete range of surfactant concentrations. About 2 weeks later (day 42, Fig. 3), a singular surfactant-free control demonstrated a strong response, which quickly $\left(0.255 \mathrm{mg} \mathrm{l}^{-1} \mathrm{~d}^{-1}\right.$ or $\left.0.00255 \mathrm{mg} \mathrm{g}^{-1} \mathrm{~d}^{-1}\right)$ approached $30 \%$ mineralization of applied phenanthrene.

The distribution of $2 \mathrm{ml}$ of well-mixed slurry from the strong-response control to all remaining samples was followed by responses of similar magnitude (first-order rates shown in Table 3 ) in the surfactant-free controls and assays with the lowest surfactant doses (day 60, Figs. 3 and 4). Following day 100 , positive responses were observed for the duplicate mid-level C12-DPDS samples (0.50 $\mathrm{mM}$ ) with a weaker response from a singular midlevel C16-DPDS sample (0.30 mM) (Figs. 3 and 4, respectively). At the highest surfactant levels (supra-CMC), a singular positive response occurred with C12-DPDS at $5.0 \mathrm{mM}$ after $160 \mathrm{~d}$ (Fig. 3) and, at a much lower rate, a supra-CMC C16-DPDS sample progressed slowly over much of the test (Fig. 4). At day 170, 1:10 dilutions were made of three unresponsive samples: $5.0 \mathrm{mM}$ C12-DPDS, 3.0 mM C16-DPDS and 0.3 mM C16-
DPDS. From both the diluted and undiluted parent samples, no significant mineralization responses were observed over a $30-\mathrm{d}$ period (data not shown). This differs from results by Laha and Luthy (1991) where a reversible inhibition at supra-CMC levels was observed using nonionic surfactants.

When assays were terminated, $\mathrm{pH}$, surface tension, and dpm in well-settled supernatants were measured in select samples as shown in Table 4. All of the sub-CMC surfactant-amended samples had estimated surfactant concentrations lower than or equal to their original design levels and the supra-CMC samples had micellar surface tension values (surface tension cannot be used to distinguish between surfactant concentrations above the CMC). With some reduction in surfactant levels being expected due to sorption and degradation, these observations demonstrate recalcitrance. Considering that C16-DPDS is inherently biodegradable (Dow Chem., 1997), the potential remains for eventual degradation in the environment. The supra-CMC samples showed marked increases in soluble dpm levels at termination confirming that solubilization was still occurring. For both surfactant types, the dpm levels among 


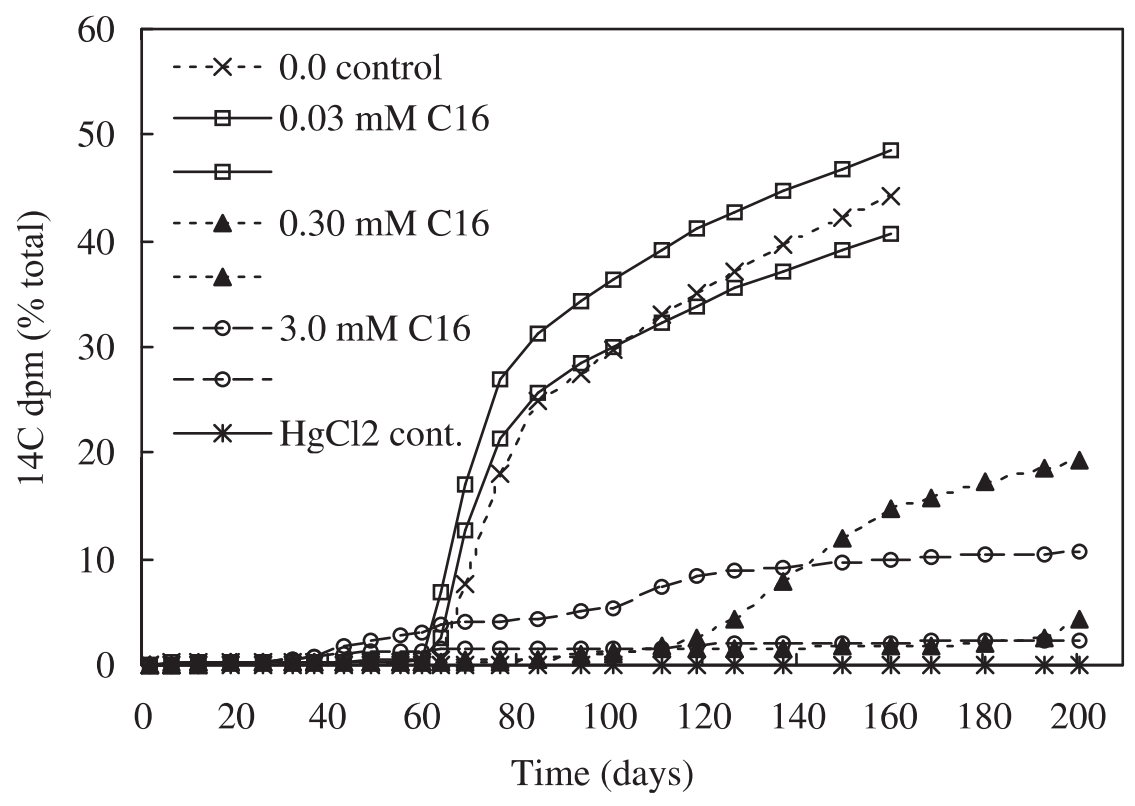

Figure 4. Accumulation of label from mineralized phenanthrene $\left({ }^{14} \mathrm{C} \mathrm{dpm}\right)$ versus time for soil-slurry systems with C16-DPDS (and controls). On day 28, $0.5 \mathrm{ml}$ of phenanthrene- degrading culture was added to each sample. On day 60, $2.0 \mathrm{ml}$ of control that had demonstrated early growth (see Fig. 3) was distributed to each remaining sample.

duplicate assays were lower in the more biologically active samples (with greater mineralization responses, see Table 4). Thus, it would appear that the route of uptake for the dominant species in these late-term supra-CMC samples was via the aqueous and/or micellar pseudo phases as opposed to the sorbed state and that the surfactants were not inhibitory. In contrast, the influence of surfactants was not beneficial and may have been inhibitory to the dominant species in the early-term of these cultures. Stelmack et al. (1999) demonstrated that the presence of surfactant (including C16-DPDS) at about half the $\mathrm{CMC}$ prevented adhesion of select bacteria to non-aqueous-phase liquids and further inhibited growth on an anthracene substrate. Similarly, Efroymson and Alexander (1991) observed that degradation of poorly soluble HCs dissolved in solvent by an Acinetobacter strain was inhibited by a nonionic surfactant that interfered with cell contact to the solvent interface. Dispersion or interference to cell adhesion on (or near) a substrate can be a significant factor for some species. Results here show some potential for phenanthrene degradation in the presence of surfactant below and above the CMC with the greater potential being with C12-DPDS. The nature of $\mathrm{HC}$ degradation responses in surfactant-free and

Table 3. First-order rate constants $\left(\mathrm{k}, \mathrm{d}^{-1}\right)$ with standard deviations (SD) for surfactant-free controls and samples with the lowest surfactant levels in the soil-slurry (Figs. 3 and 4) and saturated soil (Figs. 5 and 6) systems.

\begin{tabular}{|c|c|c|c|}
\hline $\begin{array}{c}\text { Soil-slurry } \rightarrow \\
\mathrm{k}, \mathrm{d}^{-1}(\mathrm{SD}) \rightarrow\end{array}$ & Surfactant-free & $\begin{array}{c}\text { C12-DPDS, 0.05 mM } \\
0.0225(0.0032)\end{array}$ & $\begin{array}{c}\text { C16-DPDS, 0.03 mM } \\
0.0236(0.0003)\end{array}$ \\
\hline $\begin{array}{c}\text { Saturated soil } \rightarrow \\
\mathrm{k}, \mathrm{d}^{-1}(\mathrm{SD}) \rightarrow\end{array}$ & Surfactant-free & $\begin{array}{c}\text { C12-DPDS, } 0.5 \mathrm{mM} \\
0.033(0.0063)\end{array}$ & $\begin{array}{c}\text { C16-DPDS, } 0.3 \mathrm{mM} \\
0.0091(0.0029)\end{array}$ \\
\hline
\end{tabular}


Table 4. Mineralization responses (qualitative, see Figs. 3 and 4) of soil-slurry assays and final pH, dpm, and surface tensions of select samples at termination. Initial $\mathrm{pH}$ values were 7.3 to 7.4. Surfactant concentrations estimated from surface tension ( $n d$, not determined).

\begin{tabular}{|c|c|c|c|c|c|}
\hline $\begin{array}{l}\text { Surfactant and } \\
\text { applied conc., } \\
\text { DPDS }(\mathbf{m M})\end{array}$ & $\begin{array}{l}\text { Mineralization } \\
\text { response }\end{array}$ & pH & dpm & $\begin{array}{l}\text { Surface } \\
\text { tension } \\
\left(\gamma, \mathbf{m N ~ m}^{-1}\right)\end{array}$ & $\begin{array}{l}\text { Final } \\
\text { surfactant } \\
\text { conc. }(\mathbf{m M})\end{array}$ \\
\hline $\mathrm{C} 12,0.05$ & +++ & 7.4 & 146 & 66 & 0.03 \\
\hline $\mathrm{C} 12,0.05$ & +++ & 7.2 & 144 & $n d$ & $n d$ \\
\hline $\mathrm{C} 12,0.50$ & ++ & 7.2 & 200 & $n d$ & $n d$ \\
\hline $\mathrm{C} 12,0.50$ & ++ & 7.2 & 236 & 57 & 0.2 \\
\hline C12, 5.00 & - & 7.2 & 570 & 46 & $>\mathrm{CMC}$ \\
\hline $\mathrm{C} 12,5.00$ & ++ & 7.2 & 334 & 46 & $>\mathrm{CMC}$ \\
\hline 0.0 & +++ & 6.3 & 120 & 68 & 0.02 \\
\hline 0.0 & +++ & \multicolumn{4}{|c|}{ terminated on day 60 for use as seed (see Fig. 3) } \\
\hline 0.0 & +++ & 7.4 & 166 & 68 & 0.02 \\
\hline $\mathrm{C} 16,0.03$ & +++ & 7.4 & 178 & 66 & 0.03 \\
\hline $\mathrm{C} 16,0.03$ & +++ & 7.4 & 137 & nd & nd \\
\hline $\mathrm{C} 16,0.30$ & ++ & 7.2 & 177 & 59 & 0.1 \\
\hline $\mathrm{C} 16,0.30$ & - & 7.2 & 128 & 61 & 0.1 \\
\hline $\mathrm{C} 16,3.00$ & - & 6.5 & 957 & 46 & $>\mathrm{CMC}$ \\
\hline C16, 3.00 & + & 6.6 & 790 & 46 & $>\mathrm{CMC}$ \\
\hline
\end{tabular}

supra-CMC surfactant-amended assays indicates that different species or routes of substrate utilization are involved in these two cases. Furthermore, the positive supra-CMC assay response gives some indication that following extended exposure (several weeks) some species can adapt to supra-CMC levels of these anionic surfactants and effectively utilize a poorly soluble $\mathrm{HC}$ as a substrate.

\section{Mineralization of phenanthrene in saturated soil (mud)}

For saturated soil systems, surfactant concentrations were applied over 1-1/2 orders of magnitude inclusive of the CMCs. Despite uniform preparation, by the fifth week of incubation a distinct difference in the appearances of the C12- and C16-DPDS samples was evident. All of the C12-DPDS assays (8 samples - with and without mineralization responses) had developed a less than saturated appearance with the presence of a few small gas pockets. All the C16DPDS assays (8 samples) and surfactant-free and $\mathrm{HgCl}_{2}$ controls, however, maintained a saturated appearance. Only the surfactant-free controls and the samples with the lowest sub-CMC surfactant levels for both C12- and C16-DPDS had significant mineralization responses during 5 months of testing (Figs. 5 and 6). The phenanthrene soil-water distribution for saturated soil systems differed greatly from the soil-slurries in that the aqueous concentration at equilibrium (ca. $0.7 \mathrm{mg} \mathrm{l}^{-1}$, as per Eqs. 1 and 2) was close to the solubility limit in the surfactant-free controls. With active degradation of product, the sorbed portion as well evidently was available to 


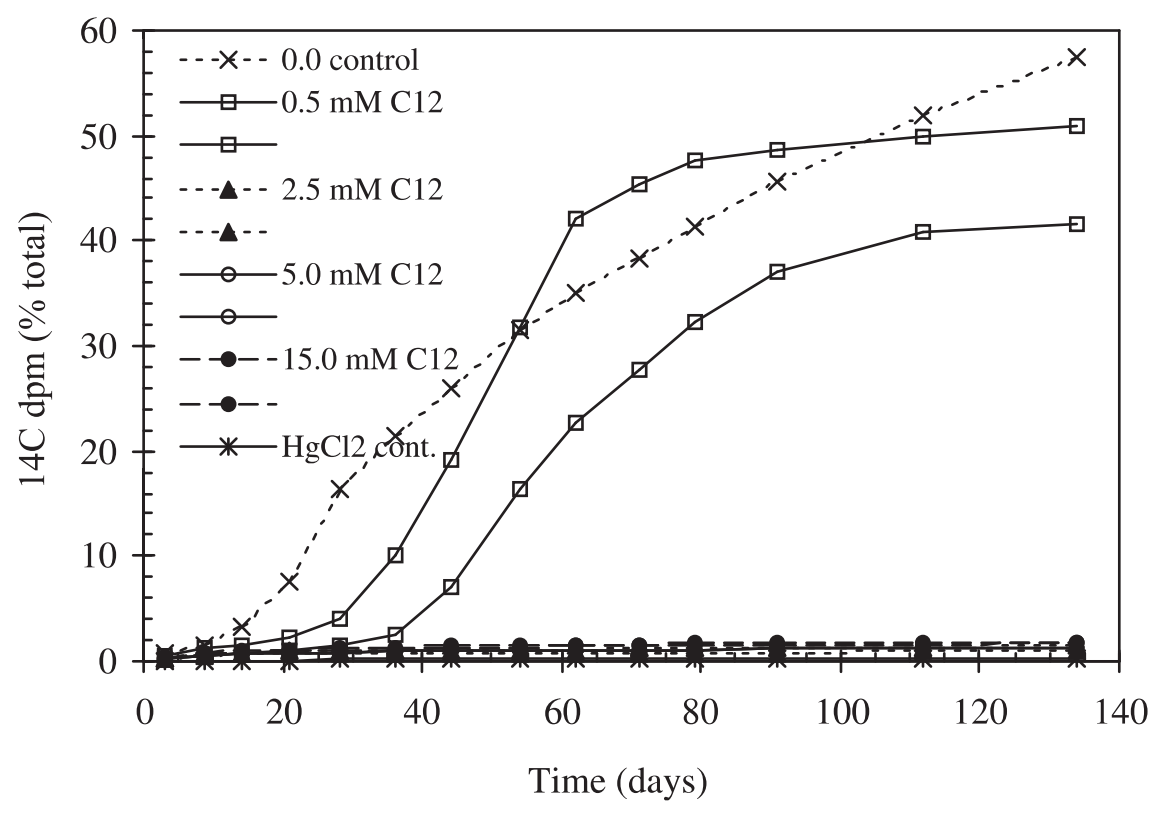

Figure 5. Accumulation of label from mineralized phenanthrene $\left({ }^{14} \mathrm{C} \mathrm{dpm}\right)$ versus time for saturated soil systems with C12-DPDS (and controls).

microorganisms either directly or indirectly via desorption.

The first-order rate coefficients for the surfactant-free controls and samples with the lowest applied surfactant concentrations for saturated soil systems are shown in Table 3. The first-order term for surfactant-free controls was about onethird that obtained with the well-mixed soil-slurries, likely due to a lack of mixing. However, results here differed from the soil-slurry systems in that the lowest surfactant levels applied, which would have minimal effect in solution, enhanced the first-order rate responses. The coefficient for C12-DPDS, in particular, was about 5 times higher than that of the surfactant-free controls with a confidence greater than $99.9 \%$. For C16-DPDS, however, significant distinction from the surfactant-free controls was only recognized with a confidence interval of $70 \%$.

Where the benefit of mixing is eliminated in the saturated soil assays, effects attributable to either surfactant-cell interactions (increased membrane fluidity) or surfactant-enhanced desorption are considered. Enhancements in desorption, however, would be greater at the higher surfactant levels. As with naphthalene in aqueous assays, though, an inhibitory threshold (other than the CMC) may preclude the use of higher surfactant concentrations. As a hypothetical consideration, seeding with a culture enriched in a surfactantamended slurry (as the late-term supra-CMC C12-DPDS slurry assay) could possibly render degradation enhancements in saturated soil systems with supra-CMC surfactant levels (an agenda of further research). Surfactant-adapted microorganisms enriched from cultures drawn from contaminated sites would potentially be well suited to survive upon reintroduction to the parent environment and to function effectively in the presence of remaining or applied surfactant during a polishing phase of remediation.

\section{CONCLUSIONS}

i) Some potential for enhancement in naphthalene degradation was evidenced with $\mathrm{C} 12$ DPDS at low concentrations, predominately below the CMC. No enhancement was observed for C16-DPDS amended assays. In both cases, there was a decreasing trend in degradation efficiency (or increasing inhibition) with an increase in surfactant concentration, with no obvious correlation to the CMCs. The influence of these anionic surfactants on biodegradation of naphthalene in aqueous assays was best understood in terms of direct interactions between surfactants and microorganisms. 


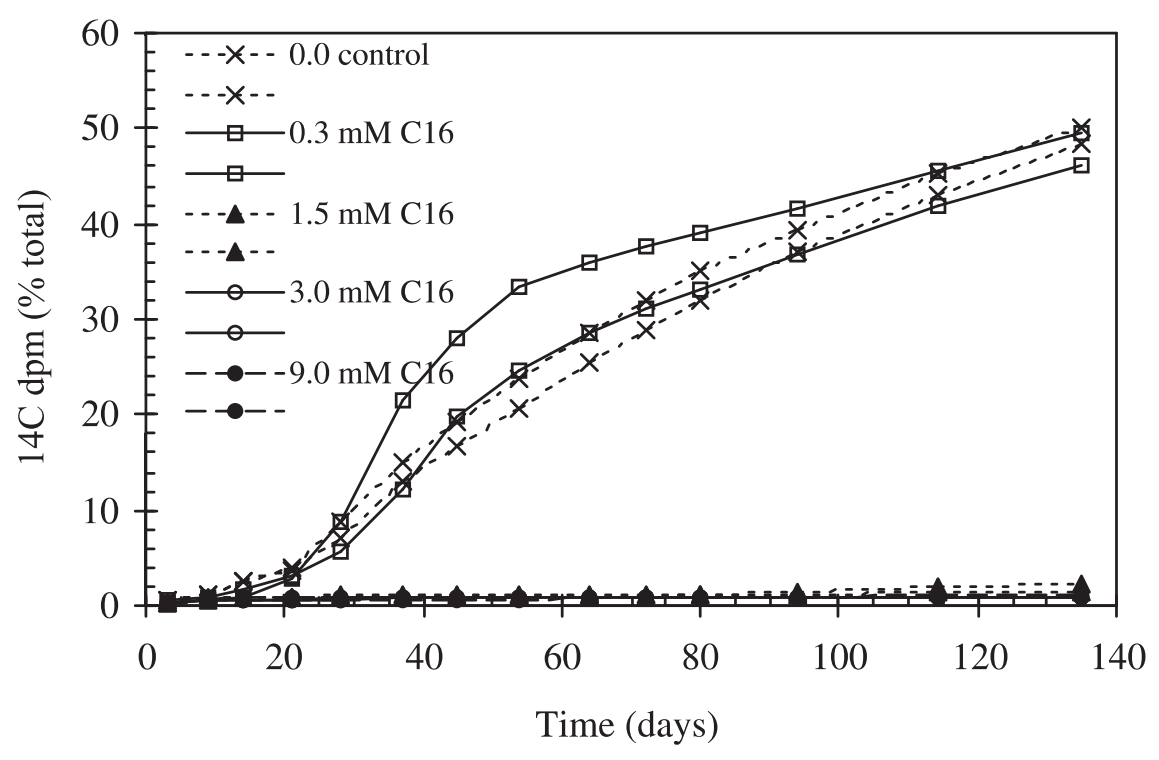

Figure 6. Accumulation of label from mineralized phenanthrene $\left({ }^{14} \mathrm{C} \mathrm{dpm}\right)$ versus time for saturated soil systems with C16-DPDS (and controls).

ii) Mineralization responses of phenanthrene in soil-slurry systems occurred first in assays without surfactant and with the lowest (subCMC) surfactant levels. Subsequent responses occurred in mid-level (sub-CMC) assays. After and extended lag period, a strong supraCMC assay response was observed using C12DPDS. The possibility of using enrichments adapted to supra-CMC surfactant levels in in situ remediation was discussed.

iii) In saturated soil (mud) systems, without mixing, mineralization responses were only evidenced in assays without surfactant or with very low surfactant additions over 5 months of testing. Mineralization responses, though, were enhanced by the low (sub-CMC) surfactant levels with the first-order rate term for C12-DPDS amended assays being 5 times higher than that of surfactant-free controls.

iv) For naphthalene in aqueous assays and phenanthrene in soil-slurry and mud assays, the greater potential for enhancement (or lesser inhibition) in biodegradation was with $\mathrm{C} 12$ DPDS. The compatibility of this surfactant, versus the C16-DPDS, with cell membrane functions is a point meriting further inquiry.

\section{REFERENCES}

Adamson, A.W. (1990), Physical chemistry of surfaces, John Wiley \& Sons, Inc., New York.

APHA, AWWA and WEF. (1995), Standard methods for the examination of water and wastewater, 19th Ed. American Public Health Association, Washington DC.

Aronstein, B.N. and Alexander, M. (1993), Effect of a non-ionic surfactant added to the soil surface on the biodegradation of aromatic hydrocarbons within the soil, Appl. Microbiol. Biotechnol. 39, 386-390.

Aronstein, B.N., Calvillo, Y.M. and Alexander, M. (1991), Effect of surfactants at low concentrations on the desorption and biodegradation of sorbed aromatic compounds in soil, Environ. Sci. Technol. 25, 17281731.

Boonchan, S., Britz, M.L. and Stanley, G.A. (1998), Surfactant-enhanced biodegradation of high molecular weight polycyclic aromatic hydrocarbons by Stenotrophomonas maltophilia, Biotechnol. and Bioengineer. 59, 482-494.

Churchill, P.F., Dudley, R.J. and Churchill, S.A. (1995), Surfactant-enhanced bioremediation, Waste Management, 15, 371-377. 
Deschenes, L., Lafrance, P., Villeneuve, J.P. and Samson, R. (1995), The effect of an anionic surfactant on the mobilization and biodegradation of PAHs in a creosote-contaminated soil, Hydrological Sciences Journal, 40, 471-484.

Deshpande, S., Wesson, L, Wade, D., Sabatini, D.A. and Harwell J.H. (2000), Dowfax surfactant components for enhancing contaminant solubilization, Wat. Res. 34, 1030-1036.

Dimonie, V.L., Vanderhoff, J.W. and El-Aasser, M.S. (1990), Application of DOWFAX surfactants in emulsion polymerization, Prepared for Dow Chemical Co., Midland, Michigan, by Emulsion Polymers Institute, Lehigh Univ., Bethlehem, Penn.

Dow Chemical Co. (1997), Product Information, DOWFAX Surfactants: Degradation of DOWFAX Surfactants. Midland, MI, USA.

Edwards, D.A., Luthy, R.G. and Liu, Z. (1991), Solubilization of polycyclic aromatic hydrocarbons in micellar nonionic surfactant solutions, Environ. Sci. Technol. 25, 127-133.

Efroymson, R.A. and Alexander, M. (1991), Biodegradation by an Arthrobacter species of hydrocarbons partitioned into an organic solvent, Appl. Environ. Microbiol. 57, 1441-1447.

Hasegawa, M.A., Sabatini, D.A. and Harwell, J.H. (1997), Liquid-liquid extraction for surfactant-contaminant separation and surfactant reuse, J. Environ. Eng. ASCE, 123, 691-697.

Hassett, J.J., Means, J.C., Barnwart, W.L. and Woods, S.G. (1980), Sorption properties of sediments and energyrelated pollutants, EPA 600/3-80-041, U.S. Environmental Protection Agency, Athens, GA.

Jahan, K., Ahmed, T. and Maier, W.J. (1997), Factors affecting the nonionic surfactant-enhanced biodegradation of phenanthrene, Water Environ. Res. 69, 317-325.

Karickhoff, S.W., Brown, D.S. and Scott, T.A. (1979), Sorption of hydrophobic pollutants on natural sediments, Water Research, 13, 241-248.

Kitamura, R. and Takada, M. (1998), Static properties of Shirasu and Shirasu ground, In: Problematic soils. Proceedings of the International Symposium on Problematic Soils, eds E. Yanagisawa, N. Moroto and T. Mitachi, p. 181. Sendai, Japan; Balkema/ Rotterdam/ Brookfield.

Knox, R.C., Sabatini, D.A. and Canter, L.W. (1993), Subsurface transport and fate processes, Lewis Publishing, Boca Raton, FL.

Knox, R.C., Sabatini, D.A., Harwell, J.H., Brown, R.E., West, C.C., Blaha, F. and Griffen, C. (1997), Surfactant remediation field demonstration using a vertical circulation well, Ground Water, 35, 948-953.

Knox, R.C., Shiau, B.J., Sabatini, D.A. and Harwell, J.H. (1999), Field demonstration studies of surfactant enhanced solubilization and mobilization at Hill AFB, Utah, In: Innovative subsurface remediation: field testing of physical, chemical, and characterization technologies, ACS Symposium Series 725, eds M.L. Brusseau, D.A. Sabatini, J.S. Gierke, and M.D. Annable, pp. 49-63, American Chemical Society, Washington, DC.

Köhler, A., Schuttoff, M., Bryniok, D. and Knackmuß, H.-J. (1994), Enhanced biodegradation of phenanthrene in a biphasic culture system, Biodegradation, 5, 93-103.

Laha, S. and Luthy, R.G. (1991), Inhibition of phenanthrene mineralization by nonionic surfactants in soil-water systems, Environ. Sci. Technol. 25, 1920-1930.

Liu, Z., Jacobson, A.M. and Luthy, R.G. (1995), Biodegradation of naphthalene in aqueous nonionic surfactant systems, Appl. Environ. Microbiol. 61, 145-151.

Lupton, F.S. and Marshall, K.C. (1979), Effectiveness of surfactants in the microbial degradation of oil, Geomicrobiol. J. 1, 235-247.

Rosen, M.J. (1989), Surfactants and interfacial phenomena, John Wiley \& Sons, Inc., New York.

Rouse, J.D., Sabatini, D.A. and Harwell, J.H. (1993), Minimizing surfactant losses using twin-head anionic surfactants in subsurface remediation, Environ. Sci. Technol. 27, 2072-2078.

Rouse, J.D., Sabatini, D.A., Suflita, J.M. and Harwell, J.H. (1994), Influence of surfactants on microbial degradation of organic compounds, CRC Crit. Rev. Environ. Sci. Technol. 24, 325-370.

Rouse, J.D., Sabatini, D.A., Deeds, N.E., Brown, R.E. and Harwell, J.H. (1995a), Micellar solubilization of unsaturated hydrocarbon concentrations as evaluated by semiequilibrium dialysis, Environ. Sci. Technol. 29, 2484-2489.

Rouse, J.D., Sabatini, D.A. and Harwell, J.H. (1995b), Influence of anionic surfactants on bioremediation of hydrocarbons, In: Surfactant-enhanced subsurface remediation: emerging technologies, ACS Symposium Series 594, eds Sabatini, D.A., Knox, R.C. and Harwell, J.H. pp. 124-140, American Chemical Society, Washington, DC. 
Rouse, J.D., Sabatini, D.A., Brown, R.E. and Harwell, J.H. (1996), Evaluation of ethoxylated alkylsulfate surfactants for use in subsurface remediation, Water Environ. Res. 68, 162-168.

Sabatini, D.A., Knox, R.C., Harwell, J.H., Soerens, T., Chen, Y., Brown, R.E. and West, C.C. (1997), Design of a surfactant remediation field demonstration based on laboratory and modeling studies, Ground Water, 35, 954-963.

Shabtai, Y. and Gutnick, D.L. (1985), Tolerance of Acinetobacter calcoaceticus RAG-1 to the cationic surfactant cetyltrimethylammonium bromide: role of the bioemulsifier emulsan, Appl. Environ. Microbiol. 49, 192197.

Shiau, B.-J., Rouse, J.D., Sabatini, D.A. and Harwell, J.H. (1995), Surfactant selection for optimizing surfactantenhanced subsurface remediation, In: Surfactant-enhanced subsurface remediation: emerging technologies, ACS Symposium Series 594, eds D.A. Sabatini, R.C. Knox, and J.H. Harwell, pp. 65-79. American Chemical Society, Washington, DC.

Smith, A.C. (1995), Examination of the use of an anionic surfactant in the bioremediation of hydrocarbons with varying degrees of bioavailability, M.S. thesis, Univ. of Oklahoma.

Stelmack, P.A., Gray, M.R. and Pickard, M.A. (1999), Bacterial adhesion to soil contaminants in the presence of surfactants, Appl. Environ. Microbiol. 65, 163-168.

Swisher, R.D. (1987), Surfactant biodegradation, In: Surfactant Science Series 18, Marcel Dekker, New York.

Tiehm, A., Stieber, M., Werner, P. and Frimmel, F.H. (1997), Surfactant-enhanced mobilization and biodegradation of polycyclic aromatic hydrocarbons in manufactured gas plant soil, Environ. Sci. Technol. 31, 2570-2576.

Van Hoof, P.L. and Rogers, J.E. (1992), Influence of low levels of nonionic surfactants on the anaerobic dechlorination of hexachlorobenzene, In: Biosystems technology development program. Bioremediation of hazardous waste, EPA/600/R-92/126, pp. 105-106, U.S. EPA, Washington, DC.

Volkering, F., Breure, A.M., van Andel, J.G. and Rulkens, W.H. (1995), Influence of nonionic surfactants on bioavailability and biodegradation of polycyclic aromatic hydrocarbons, Appl. Environ. Microbiol. 61, 1699-1705. 